\title{
Study the Correlation Between Polymorphism of MTHFR Thrombophilic Genes and Pregnancy Loss in Ahvaz City
}

\author{
Mahin Najafian', Elham Yar Ahmadi' ${ }^{*}$, Javad Mohammadi Asl², \\ Gholamreza Shariati ${ }^{2}$ and Neda Yar Ahmadi ${ }^{3}$
}

\author{
${ }^{1}$ Department of Obstetrics and Gynecology, \\ Ahavaz Jundishapur University of Medical Sciences, Ahvaz, Iran. \\ ${ }^{2}$ Department Medical Genetics, Ahavaz Jundishapur University \\ of Medical Sciences, Nour laboratory, Ahvaz, Iran. \\ ${ }^{5}$ Student of Professional Doctorate, Assistant in the Department of Gynecology, \\ Ahavaz Jundishapur University of Medical Sciences, Ahvaz, Iran.
}

http://dx.doi.org/10.13005/bbra/2084

(Received: 21 March 2016; accepted: 04 May 2016)

\begin{abstract}
Occurrence of various pregnancy losses is one of the most common problems associated with gynecology and obstetrics. It is usually known as a multi-factoral and complicated disease. One of the danger factors diagnosed so far is thrombophilic disorder. The present study seeks to investigate the correlation between polymorphism of MTHFR thrombophilic genes and repetitive pregnancy losses in Ahvaz city. This study was conducted on 114 women afflicted with autonomous pregnancy loss resorting to Nour and Narges laboratories. One-hundred and fourteen women without any past pregnancy losses were selected for control group. DNA was extracted and presence or absence of polymorphism of MTHFR thrombophilic genes (A1298C and C677T) were studied. The results of the study showed no significant difference between people with TT/677CT genotypes in women who had experienced several pregnancy losses and those in the control group $(P=\mathbf{0 . 0 6 9})$. However, a significant difference was observed between women with several pregnancy losses and control group in terms of $\mathrm{CC} / 1298 \mathrm{AC}$ genotypes $(\mathrm{P}=$ 0.000). The present study has found a significant relationship between MTHFR gene polymorphism (A1298) and several pregnancy losses, but no significant relationship was observed between MTHFR gene polymorphism (C677T) and repetitive pregnancy losses.
\end{abstract}

Keywords: MTHFR thrombophilic genes, Polymorphism, Pregnancy loss, Ahvaz, Iran.

The most common phenomenon during the first and second two months of pregnancy is pregnancy loss ${ }^{1}$. Pregnancy loss is defined as the end of pregnancy before the $20^{\text {th }}$ week. Women who have experienced consecutive pregnancy loss more than twice are referred to as suffering from recurrent pregnancy loss (RPL) ${ }^{2}$. Recurrent

\footnotetext{
* To whom all correspondence should be addressed. Tel: +98-9124572187;

E-mail: Dr.yarahmadi94@gmail.com
}

pregnancy loss is one of the most common problems associated with pregnancy and roughly $2 \%$ of women suffer from $i^{3}$. It is usually known as a multi-factoral and complicated disease and various danger factors such as genetics, infections, anatomical, hormonal and immune problems are involved in $\mathrm{it}^{4}$. Although the cause of this disease may remain unknown in some cases, about $55 \%$ of the patients are report to be afflicted with thrombophilic disorders ${ }^{5}$.

The correlation between recurrent pregnancy loss and thrombophilia is a challenging 
issue about which various studies have been consucted with contradictory results about its confirmation or rejection. Various studies have been conducted over recent years about the mutation of thrombophilic genes in women afflicted with RPL.

Some of these studies have investigated the relationship between mutation of thrombophilic genes and RPL. Although some studies have drawn a link between these two, others have rejected any such relationship. The different results achieved in these studies might be due to the different definitions of recurrent pregnancy loss and also different criteria for choosing the sample and geographic distribution.

MTHFR enzyme plays a major role in the metabolism of Folate-Methionine and Homocysteine. Plasma Homocysteine is a potentially poisonous amino acid. Her poisonous effects will be neutralized when it turns into Methionine amino acid ${ }^{10}$. Due to its negative pathologic effects on the Endothelium of Angiotensin vessels and V and VII coagulation factors, high levels of Homocysteine result in the rise of thrombin level, accumulation of Platelets and, consequently, venous thrombosis ${ }^{11-12}$. Reduction of MTHFR enzyme activity lowers the substrate for methionine synthetase. Consequently, production of methionine stops and we will have a rise in the level of homocysteine ${ }^{13}$. Polymorphisms (such as A1298C and C677T) of individual nucleotides in MTHFR encoding gene is considered to be one of the major factors which cause thrombophilia ${ }^{12}$. Considering the results achieved thereby, we may say that the mutation of the above said thrombophilic genes may play a major role in raising the danger of recurrent pregnancy loss among the Iranian women. The present research was conducted to study the influence of polymorphism of MTHFR thrombophilic genes on the potential of RPL among women in Ahvaz city.

The present research was carried out in order to evaluate the prevalence of thrombophilic genes mutation among the women with RPL in Ahvaz as well as compare the relationship between A1298C and C677T with recurrent pregnancy loss using PCR-RFLP method in the case and witness group.

\section{MATERIALSANDMETHODS}

\section{Samples collection and criteria of study}

The samples in this study were 114 women with RPL and the average age of $30.77 \pm 5.33$ with 2 or more abortions before the $20^{\text {th }}$ week. They didn't have any womb anatomical problems, cytogenetic problems, hormone problems, and sperm disorders. The number of the patients was determined using Allele frequency and other researches conducted in this field. All the samples had resorted to Nour and Narges medical-genetic laboratories from 2014 to 2015. On the other hand, 114 women with at least one successful delivery and no records of abortion were chosen as witnesses with the average age of 30.935.70. After giving them the necessary information and obtaining $5 \mathrm{ml}$ blood from the samples and witnesses and storing them in pipes containing EDTA, blood samples were sent to lab for molecular tests.

\section{Entrance to the study}

Patient group: 2 or more than 2 times of recurrent pregnancy loss.

Witness group: with at least one successful pregnancy.

\section{Leaving the study}

Patient group: records of underlying disease (diabetes, thyroid disease, hyperprolactinemia, antiphospholipid syndrome), womb anatomic disorders (congenital or acquired), ovarian surgery, spouse's sperm disorders.

Witness group: records of abortion.

\section{Genetic analysis}

Through the saturated salt standard method, genomic DNA was extracted from blood leukocytes. The following steps were taken in the saturated salt method:

1- $\quad$ Rinsing the blood twice with sterilized water for lysis of red blood cells

2- $\quad$ Rinsing with solution 1 (tris, $\mathrm{HCl}$, sucrose, $\mathrm{MgCl}_{2}$, triton 100) in order to eliminate the red blood cells

3- Using solution 2+SDS+ Proteinase $\mathrm{K}$ for the lysis of white blood cells

4- Using saturated salt for sedimentation of DNA

5- Watering DNA with $70 \%$ and $90 \%$ ethanol Then, PCR reaction was conducted according to the following schedule (table 1 ) an in 
accordance with AB-ANALITIKA kit protocol with a volume of $24 \mathrm{l}$ comprised of $20 \mathrm{l}$ PREMIX, $2.5 \mathrm{l}$ OLIGOMIX and 11 genomic DNA. It must also be remembered that PREMIX and OLIGOMIX were also available in the kit. After the PCR reaction was over, STRIP painting was carried out according to table 2.

After final rinse stage, the strips were dried and placed on the special paper of the kit which marks mutations. The mutations in each patient were determined based on a comparison with the mutations mentioned in the protocol.

\section{Statistical analysis}

The observations were fed to SPSS (ver. 22) software. Distribution of the genotypes of each mutation and the Homozygote and Heterozygote frequency in both groups was studied using Pearson's chi-square. The significance level was set to the P-Value of less than 0.05. P-Value and odd's ratio for people with RPL were measured.

\section{RESULTSAND DISCUSSION}

The present research studied the frequency of C677T and A1298C genes polymorphism in 114 women with RPL. We also studied RPL and its relative frequency among 114 women without any abortion who had at least one successful delivery. The results of studying C677T are represented in table 3.

The following ratios were recorded for the group with RPL and the witness group respectively:
$57.9 \%$ vs. $70.2 \%$ for CC genotype, $32.5 \%$ vs. $26.3 \%$ for CT genotype, and $9.6 \%$ vs. $3.5 \%$ for TT genotype. No significant relationship was observed between the case and witness groups in terms of the polymorphism of this gene and recurrent pregnancy loss $(\mathrm{P}=0.069)$.

The results of studying A1298C are represented in table 4 . The following ratios were recorded for the group with RPL and the witness group respectively: $26.3 \%$ vs. $50.9 \%$ for AA genotype, $42.1 \%$ vs. $0.0 \%$ for AC genotype, and $31.6 \%$ vs. $49.1 \%$ for CC genotype. A significant relationship was observed between the case and witness groups in terms of the polymorphism of this gene and recurrent pregnancy loss. The frequency of $\mathrm{CC}$ and $\mathrm{AC}$ genotypes in group with RPL is significantly more than what is observed in the witness group $(\mathrm{P}=0.000)$.

Several studies have been conducted in recent years in order to study the mutation of

Table 1. PCR conditions and steps used for amplification of gene targets

\begin{tabular}{lcc}
\hline Number of cycles & Temperature & Duration \\
\hline 1 & 95 & $5 \mathrm{~min}$ \\
10 & 9561 & $20 \mathrm{~s} 2 \mathrm{~min}$ \\
25 & 95 & $25 \mathrm{~s}$ \\
& 58 & $40 \mathrm{~s}$ \\
& 72 & $40 \mathrm{~s}$ \\
hold & 72 & $5 \mathrm{~min}$ \\
\hline
\end{tabular}

Table 2. Conditions used for STRIP painting

\begin{tabular}{|c|c|c|c|}
\hline Step & Required reagents & Condition of incubation & Incubation time \\
\hline $\begin{array}{l}\text { 1-Denaturation of } \\
\text { amplification product }\end{array}$ & $\begin{array}{l}10 \mu \mathrm{L} \text { amplification } \\
\text { product }+20 \text { DEN }\end{array}$ & Room temperature & $5 \mathrm{~min}$ \\
\hline 2-Hybridization & HYB-2 (prewarmed to 46) & Shaking at 46 & $30 \mathrm{~min}$ \\
\hline $\begin{array}{l}\text { 3-Stringent } \\
\text { washing }\end{array}$ & $\begin{array}{l}\text { CON-D2 (prewarmed to } \\
46 \text { ) }\end{array}$ & Shaking at 46 & 10 min \\
\hline 4-Incubation with & Diluted CON (0.5 & Shaking at 46 & $30 \mathrm{~min}$ \\
\hline $\begin{array}{l}\text { Streptavidine-AP } \\
\text { conjugate }\end{array}$ & $\begin{array}{l}\text { CON + } 1 \mathrm{ml} \text { prewarmed } \\
\text { (46) }\end{array}$ & & \\
\hline 4-Rinse & RIN & Shaking at room temperature & $2 \min$ \\
\hline 5-Rinse & RIN & Shaking at room temperature & $2 \min$ \\
\hline 6-Staining & $\begin{array}{l}\text { STAINING SOLUTION } \\
\text { (dissolve } 1 \mathrm{NBT} / \mathrm{BCIP} \\
\text { tablet in } 10 \mathrm{~mL} \text { distilled ) }\end{array}$ & $\begin{array}{l}\text { Shaking IN DARK at } \\
\text { Room temperature }\end{array}$ & $10-12 \min$ \\
\hline 7-Staining stop & STOP & Shaking at Room temperature & $2 \min$ \\
\hline 8-Final rinse & Dstilled & Shaking at Room temperature & $2 \min$ \\
\hline
\end{tabular}


Thrombophilic genes among women afflicted with RPL. Some of these studies have pointed out to the relationship between the mutation of Thrombophilic genes and RPL, while no relationship was proved in the other studies. The various results achieved in these studies may be due to different definitions of RPL and differences in the criteria for choosing the sample and geographic distribution. Studying this phenomenon and linking it with RPL is still one of the attractive issues for the researchers. Several studies have been conducted about the polymorphism effect of MTHFR enzyme on the activity of enzyme and the relationship between it (as a factor of danger) with RPL.

In the present research, the frequency of the mutated genotypes (CT and TT) of C677T polymorphism (table 1) showed no significant relationship with RPL. The result of this study on C677T was in line with the researches conducted by Zenouri ${ }^{33}$ in the north-western parts of Iran, but they are not in line with the researches conducted by Torabi ${ }^{14}$, Eskandari ${ }^{31}$ and Behjati ${ }^{32}$. In a study conducted by Torabi et al (2012), the relationship between MTHFR 1298AC and RPL was investigated and the end results were similar to the results we achieved. Abu-Asab et al. (2011) found no direct and specific relationship between the mutations and RPL. This is similar to the results of the present study about MTHFR C677T ${ }^{25}$. The study conducted by Habibovic et al. (2011) found no significant relationships in terms of MTHFR C677 ${ }^{18}$. Farah Idali et al. (2010) arrived at the conclusion that a significant relationship was observed between 1298 polymorphism, MTHFR 677 and RPL among the Iranian women ${ }^{26}$. The study conducted by Gonca (2009) found a significant relationship between MTHFR C677 and RPL. However, no significant relationship was observed in the case of A1298C whose result is not in line with the present research ${ }^{3}$. A significant relationship was observed in the studies of Goodman (2006) and Gertrud Unfried (2002) ${ }^{27}$, while Foka (2000) found no explicit relationship about this issue ${ }^{17}$. A specific relationship between these polymorphisms and RPL was rejected in the studies conducted by Vettrisevi (southern India, 2008), Makino (Japan, 2006), and Wiwanit kit (metaanalysis in Thailand, 2005) ${ }^{31}$.

These contrasting results suggest that the role of A1298C and C677T in RPL is probably influenced by the absorption of Folate in the diet and geographic and racial factors and the final phenotype is the result of the interaction between these factors. This mutation is probably tolerated in people who are rich in Folate. However, in people with a low absorption level of Folate, this mutation may result in clinical or biochemical phenotypes. Thus, the discrepancy in the level of Folate in the diet can explain the discrepancy due to the influence of MTHFR polymorphism on RPL in various societies. As the studies indicate, low

Table 3. Genotype frequency and studying the level of significance for C677T polymorphism in the case and witness group

\begin{tabular}{lcccc}
\hline Genotype & $\begin{array}{c}\text { Genotype frequency in } \\
\text { the witness group }\end{array}$ & $\begin{array}{c}\text { Genotype frequency } \\
\text { in the patient group }\end{array}$ & $\begin{array}{c}\text { Genotype frequency } \\
\text { in all those studied }\end{array}$ & P-Value \\
\hline A/A & $50.9 \%(58)$ & $26.3 \%(30)$ & $38.6 \%(88)$ & 0.000 \\
A/C & $49.1 \%(56)$ & $42.1 \%(48)$ & $40.6 \%(104)$ & 0.000 \\
C/C & $0.0 \%(0)$ & $31.6 \%(36)$ & $15.8 \%(36)$ & 0.000 \\
\hline
\end{tabular}

Table 4. Genotype frequency and studying the level of significance for A1298C polymorphism in the case and witness groups

\begin{tabular}{lcccc}
\hline Genotype & $\begin{array}{c}\text { Genotype frequency in } \\
\text { the witness group }\end{array}$ & $\begin{array}{c}\text { Genotype frequency } \\
\text { in the patient group }\end{array}$ & $\begin{array}{c}\text { Genotype frequency } \\
\text { in all those studied }\end{array}$ & P-Value \\
\hline $\mathrm{A} / \mathrm{A}$ & $50.9 \%(58)$ & $26.3 \%(30)$ & $38.6 \%(88)$ & 0.000 \\
$\mathrm{~A} / \mathrm{C}$ & $49.1 \%(56)$ & $42.1 \%(48)$ & $40.6 \%(104)$ & 0.000 \\
$\mathrm{C} / \mathrm{C}$ & $0.0 \%(0)$ & $31.6 \%(36)$ & $15.8 \%(36)$ & 0.000 \\
\hline
\end{tabular}


levels of Folate in the foods of the Indians and African communities compared to western and European societies make the former prone to some problems such as nervous pipe disorders during the fetus development and compilation of Homocysteine and failure in the synthesis and recovery of DNA. Folic acid supplements may solve the problem for women. The other effective factor in describing the contradictory results in various communities or even the results of various studies in a population include (but are not limited to) the size and composition and geographic distribution and the race of the population studied. The results of the present study indicate that MTHFR C677T polymorphism in the population studied has no significant relationship with RPL, however, this is not the case with MTHFR A1298C polymorphism.

\section{ACKNOWLEDGEMENTS}

The authors wish to thank Mr. Sarvari the laboratory technician in Narges laboratory of Ahvaz and also Ms. Golchin the laboratory technician in Nour laboratory of Ahvaz. The present investigation was supported by the Nour and Narges medical genetics laboratories in Ahvaz.

\section{REFERENCES}

1. Khaleghparast, A., Morovvati, S., Noormohammadi, Z. Evaluation of the association between the C677T and A1298C polymorphisms of MTHFR gene and recurrent miscarriage. Sci. J. Blood. Transfus. Organ., 2011; 8(2): 88-95.

2. Meka, A., Reddy, B.M. Recurrent spontaneous abortions: an overview of genetic and non-genetic backgrounds. Int. J. Hum. Gen., 2006; 6(2): 109.

3. Yenicesu, G.I., Cetin, M., Ozdemir, O., Cetin, A., Ozen, F., Yenicesu, C., Yildiz, C., Kocak, N. A prospective case-control study analyzes 12 thrombophilic gene mutations in Turkish couples with recurrent pregnancy loss. Am. J. Reprod. Immunol., 2010; 63(2): 126-36.

4. Altintas, A., Pasa, S., Akdeniz, N., Cil, T., Yurt, M., Ayyildiz, O., Batun, S., Isi, H. Factor V Leiden and G20210A prothrombin mutations in patients with recurrent pregnancy loss: data from the southeast of Turkey. Ann. Hematol., 2007; 86(10): 727-31.

5. Bick, R.L. Recurrent miscarriage syndrome due to blood coagulation protein/platelet defects: prevalence, treatment and outcome results. Clin. Appl. Thromb. Hemost., 2000; 6(3): 115-25.

6. Kupferminc, M.J. Thrombophilia and pregnancy. Reprod. Biol. Endocrinol., 2003; 1(1): 111.

7. Walker, I.D. Thrombophilia in pregnancy. $J$. Clin. Pathol., 2000; 53(8): 573-80.

8. Kazerooni, T., Ghaffarpasand, F., Asadi, N., Dehkhoda, Z., Dehghankhalili, M., Kazerooni, Y. Correlation between thrombophilia and recurrent pregnancy loss in patients with polycystic ovary syndrome: A comparative study. J. Chin. Med. Assoc., 2013; 76(5): 282-8.

9. Glueck, C.J., Wang, P., Bornovali, S., Goldenberg, N., Sieve, L. Polycystic ovary syndrome, the G1691A factor V Leiden mutation, and plasminogen activator inhibitor activity: associations with recurrent pregnancy loss. Metabolism., 2003; 52(12): 1627-32.

10. Kurzawiñska, G., Seremak-Mrozikiewicz, A., Drews, K., Barlik, M., Mrozikiewicz, P. [Genetic conditioned changes in activity of 5, 10-methylenetetrahydrofolate reductase (MTHFR) and recurrent miscarriages]. Ginekologia. Polska., 2009; 80(10): 762-7.

11. Ayadurai, T., Muniandy, S., Omar, S.Z. Thrombophilia investigation in Malaysian women with recurrent pregnancy loss. J. Obstet. Gynaecol. Res., 2009; 35(6): 1061-8.

12. Spiroski, I., Kedev, S., Antov, S., Arsov, T., Krstevska, M., Dzhekova-Stojkova, S., Bosilkova, G., Kostovska, S., Trajkov, D., Petlichkovski, A., Strezova, A., EfinskaMladenovska, O., Spiroski, M. Methylenetetrahydrofolate reductase (MTHFR-677 and MTHFR-1298) genotypes and haplotypes and plasma homocysteine levels in patients with occlusive artery disease and deep venous thrombosis. Acta. Biochim. Pol., 2008; 55(3): 587-94.

13. Van der Put, N., Van der Molen, E., Kluijtmans, L., Heil, S., Trijbels, J., Eskes, T., Van Oppenraaij-Emmerzaal, D.,Banerjee, R., Blom, H.J. Sequence analysis of the coding region of human methionine synthase: relevance to hyperhomocysteinaemia in neural-tube defects and vascular disease. QJM., 1997; 90(8): 511-7.

14. Torabi, R., Zarei, S., Zeraati, H., Zarnani, A.H., Akhondi, M.M., Hadavi, R., Shiraz, E.S., JeddiTehrani, M. Combination of thrombophilic gene polymorphisms as a cause of increased the risk of recurrent pregnancy loss. J. Reprod. Infertil., 2012; 13(2): 89.

15. Torabi, R., Karampour, M.O., 
Mohammadzadeh, A., Arefi, S., Keramatipour, M., Zarei, S., Zeraati, H., Jeddi-Tehrani, M. The Relationship between Polymorphisms of Blood Coagulation Factor V Gene and Recurrent Pregnancy Losses. J. Reprod. Infertil., 2009; 9(4): 305-17.

16. Glueck, C.J., Gogenini, S., Munjal, J., Tracy, T., Pranikoff, J., Wang, P. Factor V Leiden mutation: a treatable etiology for sporadic and recurrent pregnancy loss. Fertili. Steril., 2008; 89(2): 410-6.

17. Foka, Z.J., Lambropoulos, A.F., Saravelos, H., Karas, G.B., Karavida, A., Agorastos, T., Zournatzi, V., Makris, P.E., Bontis, J., Kotsis, A. Factor V leiden and prothrombin G20210A mutations, but not methylenetetrahydrofolate reductase C677T, are associated with recurrent miscarriages. Hum. Reprod., 2000; 15(2): 458-62.

18. Habibovic, Z., Zeybek, B., Sanhal, C., Eroglu,. Z, Karaca, E., Ulukus, M. Effects of inherited thrombophilia in women with recurrent pregnancy loss. Clin. Exp. Obstet. Gynecol., 2011; 38(4): 347-50.

19. Cao, Y., Zhang, Z., Xu, J., Yuan, W., Wang, J., Huang, X., Shen, Y., Du, J. The association of idiopathic recurrent pregnancy loss with polymorphisms in hemostasis-related genes. Gene., 2013; 530(2): 248-52.

20. Wolf, C.E., Haubelt, H., Pauer, H.U., Hinney, B., Krome-Cesar, C., Legler, T.J., Hellstern, P., Emons, G., Zoll, B., Köhler, M. Recurrent pregnancy loss and its relation to FV Leiden, FII G20210A and polymorphisms of plasminogen activator and plasminogen activator inhibitor. Pathophysiol. Haemost. Thromb., 2004; 33(3): 134-7.

21. Buchholz, T., Lohse, P., Rogenhofer, N., Kosian, E., Pihusch, R., Thaler, C. Polymorphisms in the ACE and PAI 1 genes are associated with recurrent spontaneous miscarriages. Hum. Reprod., 2003; 18(11): 2473-7.

22. Glueck, C.J., Kupferminc, M.J., Fontaine, R.N., Wang, P., Weksler, B.B., Eldor, A. Genetic hypofibrinolysis in complicated pregnancies. Obstet. Gynecol., 2001; 97(1): 44-8.

23. Soltanghoraee, H., Memariani, T., Aarabi, M., Hantoushzadeh, S., Arefi, S., Aarabi, M., Akhondi, M.M., Modarresi, M.H. Association of ACE, PAI-1 and coagulation factor XIII gene polymorphisms with recurrent spontaneous abortion in Iranian patients. J. Reprod. Infert., 2007; 7(4): 324-31.

24. Mierla, D., Szmal, C., Neagos, D., Cretu, R., Stoian, V., Jardan, D. Association of Prothrombin (A20210G) and Factor V Leiden (A506G) with Recurrent Pregnancy Loss. Maedica., 2012; 7(3):
222-6.

25. Abu-Asab, N., Ayesh, S., Ateeq, R., Nassar, S., El-Sharif, W. Association of inherited thrombophilia with recurrent pregnancy loss in palestinian women. Obstet. Gynecol. Int., 2011; 2011: 1-6.

26. Idali, F., Zareii, S., Mohammad-Zadeh, A., Reihany-Sabet, F., Akbarzadeh-Pasha, Z., Khorram-Khorshid, H.R., Zarnani, A.H., JeddiTehrani, M. Plasminogen activator inhibitor 1 and methylenetetrahydrofolate reductase gene mutations in iranian women with polycystic ovary syndrome. Am. J. Reprod. Immunol., 2012; 68(5): 400-7.

27. Goodman, C.S., Coulam, C.B., Jeyendran, R.S., Acosta, V.A., Roussev, R. Which thrombophilic gene mutations are risk factors for recurrent pregnancy loss? Am. J. Reprod. Immunol., 2006; 56(4): 230-6.

28. Unfried, G., Griesmacher, A., Weismüller, W., Nagele, F., Huber, J.C., Tempfer, C.B. The C677T polymorphism of the methylenetetrahydrofolate reductase gene and idiopathic recurrent miscarriage. Obstet. Gynecol., 2002; 99(4): 614-9.

29. Finan, R.R., Tamim, H., Ameen, G., Sharida, H.E., Rashid, M., Almawi, W.Y. Prevalence of factor V G1691A (factor V Leiden) and prothrombin G20210A gene mutations in a recurrent miscarriage population. Am. J. Hematol., 2002; 71(4): 300-5.

30. Reznikoff-Etievant, M., Cayol, V., Carbonne, B., Robert, A., Coulet, F., Milliez, J. Factor V Leiden and G20210A prothrombin mutations are risk factors for very early recurrent miscarriage. Br. J. Obstet. Gynaecol., 2001; 108(12): 1251-4.

31. Eskandari, F., Akbari, M.T., Zare Karizi, S.H. Association of C677T and A1298C Polymorphisms of the MTHFR gene with recurrent pregnancy loss. Pejouhandeh., 2013; 18(4): 167-173.

32. Behjati, R., Modarressi, M.H., Jeddi-Tehrani, M., Dokoohaki, P., Ghasemi, J., Zarnani, A.H., Aarabi, M., Memariani, T., Ghaffari, M., Akhondi, M.A. Thrombophilic mutations in Iranian Patients with infertility and recurrent Spontaneous abortion. Ann. Hematol., 2006; 85: 268-71.

33. Zonouzi, P.A., Chaparzadeh, N., Asghari, E.M., Mehrzad, S.M., Farzadi, L., Ghasemzadeh, A., Sakhinia, M., Sakhinia, E. Methylentetrahydropholate reductase C677T and A1298C mutation in women with recurrent spontaneous abortions in the Northwest of Iran. ISRN. Obstet. Gynecol., 2012; 2012: 1-6. 